\title{
Exploring Undergraduate Students' Understanding of Shari'ah Based Audit: Implications for the Future of Shari’ah Auditing Labor Market in Brunei
}

\author{
Hisham Yaacob (Corresponding author) \\ Department of Accounting \& Finance, Faculty of Business, Economics \& Policy Studies \\ University of Brunei Darussalam, Tungku Link, Gadong, Brunei BE1410 \\ E-mail: Hisham.yaacob@ubd.edu.bn
}

Fathima Shafeek

University of Brunei Darussalam, Brunei

Hairul Suhaimi Nahar

Universiti Putra Malaysia, Malaysia

Received: July 22, 2013 Accepted: September 11, 2013 Published: December 1, 2013

doi:10.5296/ajfa.v5i2.4039ＵRL: http://dx.doi.org/10.5296/ajfa.v5i2.4039

\begin{abstract}
The worldwide Islamic finance industry had grown remarkably in the past decades, primarily propelled by the strong demand for shari'ah (Islamic Law) compliant banking products by Muslims and non-Muslims alike. Behind the façade of such outstanding industry's development, there remain unresolved critical governance issues warranting for immediate attention by industry stakeholders. Besides the presence of significant variations with regards to the scope and framework for shari'ah audit in the currently available shari'ah governance policy standards, another imperative issue surrounds the relatively small pool of knowledgeable and competent shari'ah auditors (vis-à-vis conventional auditors) to perform shari'ah auditing of Islamic financial transactions and hence, the institutions. Arguably, these pose a significant threat to the coordinated development of this religiously rooted industry. The study's conjecture is that education holds the key to resolve the issue. Accordingly, it
\end{abstract}


undertakes a preliminary survey on Bruneian undergraduate students in the field of accounting, business and shari'ah related, majority of whom are expected to be part of Brunei's future shari'ah auditing labor market. The study finds that students' understanding of shari'ah auditing is arguably "rudimentary" in nature. While the characteristics and knowledge expected of shari'ah auditor are well understood, the students are however unsure of the primary objective for shari'ah auditing. These highlight the practical imperative for the Brunei government to consider a holistic revamp of its education strategies in meeting future market demands for qualified and well trained shari'ah auditors.

Keywords: Islamic accounting, Islamic finance, Shari'ah audit, Shari’ah auditor 


\section{Introduction}

Islamic finance has become a credible alternative to conventional, usury-based financing industry, registering a growth in excess of $20 \%$ in the past decades (Global Islamic Finance, 2012). The religiously rooted industry has more than three hundred industry players called “Islamic Financial Institutions (IFIs)" operating in almost eighty countries globally with total assets stood at US\$1.3 trillion in 2011 (Grewal, 2012; PwC, 2011) and reached US\$1.6 trillion in 2012 (Global Islamic Finance, 2012). The Islamic finance assets in the Asian region alone constitute $22 \%$ of that amount (Grewal, 2012). Official statistics produced by KFH Research, an independent professional research house indicate that Islamic banking activities primarily drive the industry's expansion globally with an estimated asset size of USD1.1 trillion as at 2011, which value attributed to almost $81 \%$ of the whole shari'ah based finance assets worldwide. This is followed by sukuk (Islamic bond) with $14 \%$ Islamic finance assets portion, equivalent to approximately USD178.2 billion outstanding sukuk value as at 2011. The global Islamic finance assets are further expanded by the Islamic fund management activities (4.5\%) which assets under management closed to USD60 billion from 876 funds as at 2011. The remaining portion of the world Islamic finance assets $(0.5 \%)$ as at 2011 came from Takaful (Islamic insurance).

Amongst the growing Islamic finance market in South East Asia (SEA) is a small Islamic Nation of Brunei, a sovereign state located on the north Coast of Borneo Island. The country's population stood slightly above four hundred thousand as at July 2011 (US Department of State, 2011). Despite its small size geographically, Brunei recorded the second highest Human Development Index (HDI) among SEA nations (Singapore being the first) and this small Nation is classified as a "developed country" (United Nation, 2011). Consistent with its "developed country" status, Brunei is ranked fifth in the world by gross domestic product per capita at purchasing power parity of approximately US48,000 per capita (International Monetary Fund, 2011). This makes Brunei the fifth richest nation out of 182 nations in the world, primarily due to its extensive petroleum and natural gas field exploration and discovery activities.

The Brunei Islamic finance industry was practically introduced in 1991 following the establishment of the Country's Trust Fund named Tabung Amanah Islam Brunei Darussalam, followed by the conversion of a conventional bank (Island Development Bank) into a full-fledged Islamic bank (Islamic Development Bank of Brunei (IDBB)) in January 1993 and later merged with Bank Islam Brunei Darussalam (BIBD). Among the Country's notable Islamic finance progress includes the introduction of equity-based Islamic products of Musharakah (partnership) to finance Small and Medium Enterprises (SMEs) and a home-ownership financing based on Musharakah Mutanaqisaha instrument by BIBD in 2010. Sukuk (Islamic bond) issuance remains a rare debt instrument in Brunei with only two issuances to date. Its first Sukuk Ijarah was only available in 2006, issued by the then IDBB and subsequently a short-term money market Sukuk Ijarah program issued by the government.

The government continuously supports the Islamic finance development by providing the necessary infrastructure including the establishment of a regulatory authority called "Autoriti 
Monetari Brunei Darussalam” in 2010. It takes up the role of a central bank for Brunei, functions as a government institution that supervises and regulates the operations of the country's Islamic banks. Further, the Centre for Islamic Banking, Finance and Management (CIBFM) was also established in 2012 by the Ministry of Finance, which aims at developing human talents required for the industry. Among others, it provides professional learning courses in various academic disciplines including banking, finance, insurance, capital market as well as general management.

At the global front, the immediate observable impacts arising from the emergence of Islamic finance industry are diverse. Among others it includes the surfacing of Islamic accounting to cater for the accounting and reporting requirements of Islamic financial transactions, shari'ah governance in the form of shari'ah audit or review, the consistent and increasing demand for knowledgeable and qualified individuals to serve as shari'ah advisors and shari'ah supervisory board members, and finally the official establishment of standard setters for IFIs such as the Accounting and Auditing Organization for Islamic Financial Institution (AAOIFI) and the International Financial Services Board (IFSB). The former is an international non-profit organization established in 1991 which main objectives are to develop and disseminate Islamic based accounting and auditing thought and standards for IFIs. The latter on the other hand issues standards and guiding principles with the aim of promoting and enhancing prudential stability of the Islamic financial services industry globally.

Behind the façade of such outstanding industry's development however, there remain unresolved critical issues warranting for immediate attention by industry stakeholders. The notable major impediments to the coordinated growth of this sacred industry include weak Islamic finance supporting infrastructure in markets in which Islamic finance activities are currently operating (PwC, 2011). It covers that of legislative, regulatory, legal, accounting, tax, human capital and shari'ah governance and business framework. In the specific context of shari'ah governance, the shari'ah audit in effect pillars the shari'ah governance framework of IFIs by providing independent assurance to IFI's diverse stakeholders on matters related to IFI's operations including products and services (Mohamed-Ibrahim, 2008). This effectively ensures that IFIs are operating strictly within a shari'ah based operating environment.

Prior academic literature specific on shari'ah audit has indeed highlighted prevalent problems facing the Islamic finance industry which include the small and limited pool of available skilled human capital (Kasim, Mohamed-Ibrahim and Sulaiman, 2009) in terms of knowledge and qualification (Rammal and Parker, 2010) and lack of proper shari'ah audit framework (Shafii, Salleh and Shahwan, 2010). Yaacob and Donglah (2012) conduct a survey in Brunei but they are using the postgraduate students as sample. They find that the postgraduate students' lack of understanding of shari'ah auditing is mainly due to inadequate exposure by the institutions of higher learning and the industry. The study conclude that there is an impending need to promote shari'ah audit as a future potential career in order to address the shortages of talent (qualified and knowledgeable manpower) in the Islamic finance industry. Recent survey (in 2011) conducted by PriceWaterhouseCoopers (PWC), a global professional accounting firm in Malaysia further reveals alarming shari'ah governance issues 
including the urgency in expanding the talent pool of shari'ah auditors, enhancing the comprehensiveness of shari'ah audit scope and improving shari'ah audit methodologies (PwC, 2011).

Arguably, the above identified problems represent a significant threat to the coordinated development of this religiously rooted industry. The study's conjecture is that education holds the key to address the above human capital issues. Accordingly, it undertakes a preliminary survey on Bruneian undergraduate students (currently enrolled in business and management related programs), whom are expected to be part of the country's shari'ah auditing labor market in the future. The survey aims at gauging undergraduates' knowledge on shari'ah auditing and their propensity of choosing shari'ah auditor as a prospect career. Among others, the students were asked on their perceptions with regards to shari'ah auditor's roles and responsibilities, characteristics needed for a shari'ah auditor and their current understanding with respect to the most suitable qualification(s) to become a shari'ah auditor.

The study finds that the understanding of Bruneian students towards shari'ah auditing is "rudimentary" on average. They understood well the characteristics and knowledge expected of shari'ah auditor but surprisingly however, they are unsure of the primary objective for shari'ah auditing activities. The results underscore the practical imperative for the Brunei government to consider a holistic revamp of its education strategies in meeting future market demands for qualified and well trained shari'ah auditors. The study considers the awareness on Islamic finance and its components among the undergraduate students as a crucial educational strategy as awareness forms part of the self-development processes. Awareness is however expires only when individuals deemphasize the importance of acquiring and broadening their knowledge frontier.

The paper is organized as follows: A discussion on auditing in general is presented next, followed by discussion on shari'ah audit. The roles, responsibilities and code of ethics of shari'ah auditor are also presented with the aim of putting the empirical survey into perspective. This is followed by sections explaining the empirical approach to the survey and its corresponding results. Final section presents relevant discussions arising from the empirical results, conclusion and some recommendations and suggested future research.

\section{Auditing as a Discipline and Profession}

Auditing is a specialized field which practically branches out from accounting. It involves individuals referred to as "auditors" to undertake the responsibilities of attesting that the "auditee(s)"-the one being audited have done their work according to prescribed pre-agreed rules, standards or regulations. Audit comes in various forms including but not limited to financial, management and performance audit. In the specific context of financial audit, the American Accounting Association (AAA) defines auditing as:

"A systematic assessments of evidences regarding economic events and to ascertain the correspondence of the two and communicate the results to interested users". (www.aaahq.org/audit) 
In a much broader context, the International Federation of Accountants (IFAC), the global umbrella body for the accountancy profession defines auditing as:

“An independent examination of financial statements or related financial information of an entity whether profit or not, irrespective of its size, or legal form, when such examination is conducted with a view to expressing an opinion thereon". (www.ifac.org)

Audit process is usually performed at auditee's premises during which an auditor will comprehensively assess auditee's systems and records for among others, accuracy and validity. This involves audit activities of analyzing firm's relevant risks as well as identifying system's loopholes and subsequently recommending the necessary controls. These practically require auditors to understand client's business processes and environment. In the specific context of financial audit, auditing activities and the corresponding independently expressed audit opinions conceptually adds credence to the financial statements produced by firm's management. Accordingly, this helps building confidence among financial statement users in relying on the audited financial statements to make appropriate and relevant decisions (Karim, 1990).

The auditing profession and hence its activities are primarily guided by professional standards called the International Standards on Auditing (ISA) issued by IFAC through the International Auditing and Assurance Standards Board (IAASB). Mirroring the operations of International Accounting Standard Board (IASB), the IAASB operates as an independent standard-setting body with the focus of serving the public interest by developing quality auditing and assurance standards as well as facilitating the convergence of international and local (national) auditing and assurance standards. Similar to the expected end results of global convergence to International Financial Reporting Standards (IFRS) developed by IASB, the IAASB also envisaged that the convergence efforts towards single assurance standards would improve the quality and consistency of global auditing practices, thereby strengthening public confidence in the auditing and assurance profession.

\section{Shari’ah Audit}

Extant literature on auditing claims that shari'ah based auditing is relatively new, the earliest being after the emergence of IFIs during 1980s. The Islamic history however explains the reverse whereby the institution of hisbah was noted to have already established during the time of Prophet Muhammad (Peace Be Upon Him). It aims at assisting human being in worshipping Allah the Almighty by ensuring Allah's rights and the rights of other human beings are being properly observed and fulfilled. Even though it was institutionalized for the purpose of enjoining good and forbidding evil in general (as oppose to focusing specifically on economic and commercial activities), it forms an integral part of wider effort in establishing just economy in the society (Kasim et al., 2009). The contemporary role of the shari'ah auditor resembles the role of muhtasib in the traditional hisbah institution in the early period of Islam (Yaacob, 2012). The muhtasib or al-khatib audits and checks on compliance and subsequently suggests recommendations on worldly matters from shari'ah perspective (Kasim, 2010). Arguably, while shari'ah audit may have some similarities with that of social 
accountability audit (e.g. see Courville, 2003) in the specific context of auditing techniques, it is however significantly different in their respective philosophy.

The fact that auditing is not peculiar to the religion of Islam is further substantiated by the availability of auditing essence in various verses in the main source of knowledge to the Islamic religion called Al-Quran. The book is considered as the most sacred scriptures to Muslims and it contains the words of Allah which was sent down to His Messenger, Prophet Muhammad (pbuh). The followings are several audit related verses found in the Holy Scriptures:

"Then as for he who is given his record in his right hand, He will be judged with an easy account, and return to his people in happiness" (Quran, 84:7-9)

"And indeed, [appointed] over you are keepers, Noble and recording. They know whatever you do"

(Quran, 82:10-12)

The above verses indicate that Muslims (and non-Muslims alike) will be audited by Allah in the hereafter, during which human book of deeds will be presented and human will subsequently be rewarded or punished based on the "audit outcome". Comparably and in the specific context of Islamic financial system, shari'ah audit presents a system of compliance checking on its operations with regards to shari'ah rulings. The reward and punishment system comes in the form of public perceptions (negative or positive) and confidence towards the shari'ah based products offered by the IFIs. Consistent with such indirect Quranic explanation on auditing, shari'ah auditing has been comprehensively defined by Mohamed-Ibrahim (2008) as "a systematic process of objectively obtaining and evaluating evidence regarding assertions about socio-economic, religious and environmental actions and events in order to ascertain the degree of correspondence between those assertions and shari'ah, and communicating the results to users” (p.22).

The AAOIFI on the other hand provides a liberal view of audit from shari'ah perspective by merely referring it to the term "shari'ah review" without any further specifications. In AAOIFI's documents, the term "shari'ah audit" is used interchangeably to represent the checking of IFI's financial statements. The objective of IFI's auditing according to AAOIFI is "to enable the auditor to express an opinion as to whether the financial statement are prepared, in all material respects, in accordance with shari'ah rules and principles, the accounting standards of AAOIFI and relevant national accounting standards and practices in the country in which the financial institution operates" (AAOIFI, 2010).

Shari'ah audit primarily aims at singularizing the religiously rooted financial system from its conventional counterpart, by undertaking the role of certifying the validity and enforceability of Islamic financial contracts adopted. Such role which is absent in the conventional financial system effectively addresses stakeholders' perceptions and hence public confidence towards IFI's operations. In a wider context, shari'ah audit forms an integral structure to the internal governance mechanisms of IFIs by providing the necessary supervision and monitoring towards the whole spectrum of IFI's operations (Garas and Pierce, 2010). 
Accumulating academic literature (empirical and theoretical) has highlighted critical problems associated with shari'ah auditing. Khan (1985) for instance in discussing the role of shari'ah auditor, argues the unreasonable situation of having auditors 'ingrained with secular capitalist philosophy' to audit IFIs on matters relating to shari'ah compliance. Khan (1985) further suggests that auditing on IFIs must ideally be done by auditors trained in accounting and audit, as well as having the necessary knowledge on shari'ah and fiqh. Recent survey by Grais and Pellegrini (2006) reveals the fact that the existing compliance structure in IFIs is alarmingly inadequate to address the issues of shari'ah compliance. They argued that the reliance on internal shari'ah review alone provides little assurance to IFI's customers on the entity's compliance level towards shari'ah rulings in their operations. Perhaps the most observable problem in shari'ah auditing is the lack of expertise and human talent to perform shari'ah audit, a point highlighted by Besar, Abd-Sukor, Abdul-Muthalib et al., (2009) in their recent survey in the Malaysian context.

\section{Desirable Ethical Dimensions of Shari'ah Auditor}

The shari'ah highly emphasizes morality or ethics in human conduct, consistent with the sayings of Prophet Muhammad (pbuh) (the hadith):

"I have been sent to complement the noblest morals".

Accordingly, individuals undertaking shari'ah auditing activities are expected to have the following fundamental characteristics (not exhaustive) as promulgated by the Islamic religion. The first is integrity, referring to individual's consistency with his or her innate purpose (Quran, 7:26). It reflects the extant of individual's life being kept in alignment with their intrinsic function of worshipping Allah (Quran, 51:52). Integrity effectively requires shari'ah auditor to be honest and truthful in all actions. As the end output of shari'ah auditing comes in the form of independent opinion with regards to shari'ah (non)compliance, observing integrity ensures accurate and impartial opinions by auditors. In this regards, accurate and impartial opinions further require auditors to be well-versed in their discipline and able to exercise authority with high competency. Islam further emphasizes the characteristics of vicegerency (khalifah) and accountability (Haniffa and Hudaib, 2010; Nahar and Yaacob, 2011). Human beings in Islam are effectively temporary trustee to resources available on earth (Haniffa and Hudaib, 2010). Being Allah's vicegerent, human undertook the responsibility (taklif) of being the khalifah in this world.

Allah says in the Quran:

Truly, we did offer Al-Amanah (the trust or moral responsibility or honesty and all the duties which Allah has ordained) to the heavens and the earth, and the mountains, but they declined to bear it and were afraid of it (i.e. afraid of Allah's torment). But man, bore it. Verily, he was unjust (to himself) and ignorant (of the results)" (Quran, 33:72).

Undertaking the responsibility necessitates human to take care and develop this world according to Allah's will. They will subsequently be made accountable for whatever (in)actions or decisions they made in this world (Nahar and Yaacob, 2011). Shari'ah auditors are therefore expected to constantly observe strong ethical values as the auditing tasks are 
principally an amanah (trust) to be questioned in the hereafter. The trust of expressing independent, correct and impartial opinions bears great repercussion not only to the auditors but also to other individuals relying on their opinions.

\section{Investigating Undergraduate Student's Understanding of Shari'ah Auditing: The Method}

This empirical work aims at investigating Bruneian undergraduates' knowledge on shari'ah auditing and their propensity of choosing shari'ah auditor as a prospect career. Specifically, the students were asked on their perceptions with regards to shari'ah auditor's roles and responsibilities, shari'ah auditor's characteristics and their current understanding with respect to the most suitable qualification(s) to become a shari'ah auditor. Adopting a quantitative approach, this study used self-developed questionnaire survey to gather primary data from respondents. This is considered as the most appropriate method in collecting perspective information from respondents (Ghauri and Gronhaug, 2010).

There are only three universities currently operating in Brunei (University A, B and C), all of which are used as the research sample. University A is the oldest university in the country, established nearly three decades ago. University B is a full-fledged Islamic university while university $\mathrm{C}$ is the youngest university, a former technical college recently upgraded to university status. All universities currently offer bachelors degree in business, economics, finance and accounting related programs. University A is the only university in the country which currently offers Masters Course in Islamic finance by coursework and by research.

Target respondents are undergraduate students in the field of business, finance, accounting and shari'ah. These students are selected as they are expected to become part of shari'ah auditing labor market in the future. Prior study by Yavas \& Arsan (1996) found that students with accounting or auditing academic background are very likely to favor auditing as their career of choice. As shari'ah auditors are also expected to possess business and shari'ah knowledge, students enrolling in these two courses are also considered. First year students were also surveyed as they were found in previous studies to have made decisions with regards to their choice of profession during the first two years of their university studies (Gul et al., 1989; Mauldin et al., 2000; Paolillo and Estes, 1982).

A total of 69 students agreed to participate in the survey, representing 27\% from University A, $40 \%$ from University B and 33\% from University C. The number is reasonable as students' enrolment is on average, relatively small across the three universities given the small country's population. Further, a portion of the wealthiest elite societal group in the Country sent their children overseas (mainly western Nations) for quality education abroad, leaving a handful of youth to populate local universities. From the 69 copies of questionnaires distributed, 10 were unusable leaving only 59 copies available for analysis.

\section{The Understanding of Undergraduate Students Towards Shari'ah Auditing: Findings and Discussions}

Table 1 to 3 below explain respondents' demographic information, with 29\% of them are male and the remaining $71 \%$ are female. Majority of respondents (95\%) are in the age range 


\section{Macrothink}

Asian Journal of Finance \& Accounting ISSN 1946-052X 2013, Vol. 5, No. 2

of twenty (20) to twenty four (24) years old and mostly in their second and third year of study (87\%). Only eight (8) respondents (13\%) are in their final year of study.

Table 1. Gender distribution $(n=59)$

\begin{tabular}{lll}
\hline Gender & Frequency & Percentage \\
\hline Male & 17 & 29 \\
Female & 42 & 71 \\
Total & 59 & 100 \\
\hline
\end{tabular}

Table 2. Age distribution $(n=59)$

\begin{tabular}{lll}
\hline Range & Frequency & Percentage \\
\hline $15-19$ & 1 & 2 \\
$20-24$ & 56 & 95 \\
$25-34$ & 2 & 3 \\
Total & 59 & 100 \\
\hline
\end{tabular}

Table 3. Year of study distribution $(\mathrm{n}=59)$

\begin{tabular}{lcc}
\hline Year of Study & No & $\%$ \\
\hline $2^{\text {nd }}$ & 24 & 41 \\
$3^{\text {rd }}$ & 27 & 46 \\
$4^{\text {th }}$ & 8 & 13 \\
Total & 59 & 100 \\
\hline
\end{tabular}




\section{Macrothink}

Table 4 below shows the distributions of respondents according to their currently enrolled program. It indicates that almost all universities offer courses in finance with University $\mathrm{C}$ having the highest number of students enrolling for the course. University B being the sole full-fledged Islamic university in the country is the only university providing respondents studying shari'ah.

Table 4. Enrolled program distribution $(\mathrm{n}=59)$

\begin{tabular}{|c|c|c|c|c|}
\hline \multicolumn{2}{|c|}{ Enrolled program } & \multirow[b]{2}{*}{5} & \multirow{2}{*}{$\begin{array}{l}\text { Enrolled program } \\
\text { Economics }\end{array}$} & \multirow{2}{*}{$\begin{array}{l}(\%) \\
2\end{array}$} \\
\hline U. A & Business administration & & & \\
\hline & Accounting \& Finance & 18 & Others & 2 \\
\hline \multirow[t]{2}{*}{ U. B } & Islamic Finance & 18 & Business Management & 3 \\
\hline & Shari'ah & 14 & Others & 5 \\
\hline \multirow[t]{3}{*}{ U. C } & Accounting & - & Management & - \\
\hline & Finance\& commerce & 2 & Others & - \\
\hline & Finance & 31 & & - \\
\hline
\end{tabular}

Table 5. Shari'ah auditor's role $(\mathrm{n}=59)$

Shari'ah auditors role

(\%)

a) To express an opinion on the true and fair view of the $36 \%$ financial statements

b) To check that IFIs activities are shari'ah compliant $24 \%$

c) Both $40 \%$ 


\section{Macrothink}

Table 5 above indicates that only $40 \%$ of the respondents expect shari'ah auditors to do both jobs of the normal financial auditors (i.e. expressing opinion as to whether the audited financial statements provide a true and fair view of IFI's financial positions) and the true role of shari'ah auditors (i.e. checking IFI's shari'ah compliance). This implies that majority of undergraduate students surveyed (60\%) are not aware of what the precise role of shari'ah auditors. This is unsurprising as there are no specific academic courses or sections in any courses that touch on shari'ah auditing. The $40 \%$ view is however commendable as their understanding is apparently based on piecemeal knowledge of conventional auditing and shari'ah in isolation.

Table 6. Characteristics of shari'ah auditors

\begin{tabular}{lc}
\hline Characteristics & $\mathbf{( \% )}$ \\
\hline Honesty & 92 \\
Accountability & 81 \\
Highly Ethical & 78 \\
Confidentiality & 68 \\
Competency & 64 \\
Independence & 41 \\
\hline
\end{tabular}

Respondent's views on the characteristics of a shari'ah auditor (based on AAOIFI) indicate high awareness among Brunei undergraduate students towards the expected characteristics traits of shari'ah auditors. They ranked honesty as the first expected trait (92\%), followed by accountability (81\%), highly ethical (78\%), confidentiality (68\%), competency (64\%) and the least is independence (41\%). The low scoring on independence trait could potentially be attributed to their misconception with regards to the status of shari'ah auditor being part of the company, equivalent to the internal auditor or company's shari'ah advisors. 
Table 7. Knowledge needed in a shari'ah audit profession

\begin{tabular}{lc}
\hline Discipline & $\mathbf{\%}$ \\
\hline Islamic Finance & 93 \\
Shari'ah & 92 \\
Auditing & 81 \\
Accounting & 78 \\
Conventional Finance & 53 \\
\hline
\end{tabular}

Students were also asked of their views with regards to the necessary knowledge background to become shari'ah auditor. They ranked Islamic finance as the most important knowledge background (93\%) followed by shari'ah (92\%), auditing (81\%), accounting (78\%) and the least important is conventional finance (53\%). This reflects student's single-sided views whereby checking on shari'ah compliance to them requires little, if not none of conventional finance knowledge. This view effectively disregards the fact that Islamic finance knowledge is primarily developed based on conventional finance techniques modified to suit shari'ah requirements. Knowing both dimensions of finance essentially enables shari'ah auditors to analyze financial transactions and subsequently check on shari'ah compliance more effectively.

The final part of the questionnaire deals with questions of whether the profession of shari'ah auditor should be further emphasized in the Muslims dominated country and the student's view of making shari'ah auditor as a career choice. An overwhelming response of $91 \%$ agrees that shari'ah auditing should be properly developed and the regulatory framework and structure must be strengthened. These necessitate for this religious based profession to provide more exposure to potential participants in its labor market. Among common reason given by respondents in the questionnaire is the fact that Brunei is a country established under the Malay Islamic Monarchy system, with majority of the population are Muslims. This reinforces the practical imperative of properly developing the Islamic finance and putting it in the mainstream financing industry. Therefore, having a sound shari'ah auditing framework in fortifying the industry's integrity is not an option to Brunei.

Unfortunately, nearly three quarter of the respondents (approximately 70\%) confirms that they are not aware of shari'ah audit being another profession available in their career choice list. A heartening rate of $60 \%$ of the respondents however plans to consider shari'ah audit as their prospect career upon graduation. These results should send a clear alarming signal to the Bruneian government as the development of this religiously based industry is known to be a function of human capital development. Coordinated efforts are imperatively required to 
expose shari'ah audit as another promising profession in light of the industry's robust and exponential development.

In this regard, the government in collaboration with industry players and academia should therefore work towards developing a strategic, short and long term blue print for human capital development in meeting the industry needs. For instance, comprehensive revamp of the current academic curriculum should be done to reflect the market demand for knowledgeable and competent shari'ah auditor. For instance, universities in Brunei should consider incorporating shari'ah audit and Islamic finance as core subjects in their degree programs, or at least part of the respective conventional courses, even though the degree programs may not be purely Islamic. This should preferably be done at the earlier year of student's study period as the first course taken by students at undergraduate level provides significant impact on students' perceptions towards the prospective profession (Jackling and Calero, 2006).

A more ambitious plan when the knowledge has been fully developed is to have stand-alone courses on shari'ah auditing and Islamic accounting and finance. As for graduated individuals without shari'ah knowledge, educational and professional institutions may offer a focused certified shari'ah programs, providing them with the necessary shari'ah knowledge of becoming shari'ah auditor. On the other hand, shari'ah graduates without accounting and finance background could also be offered courses on accounting and finance certification, thereby offering them with equal opportunities of becoming shari'ah auditors.

Apart from that, industry-academic linkages must also be further strengthened, engaging in activities that disseminate relevant information on Islamic finance including shari'ah audit to the public. IFIs could consider organizing frequent visits to higher institutions and employment roadshow to public, informing the "positive sides" of the profession such as vast employment opportunities available in the industry and long term career prospect (Dalci, Arasli, Tumer et al., 2013) particularly on shari'ah auditing.

\section{Conclusion}

Despite the exponential growth of the Islamic finance industry and the fact that it forms an integral part of the industry's governance structure, shari'ah audit has perplexingly gained scarce attention (Sultan, 2007). The focus of both academic research and industry's attention mainly falls on the industry's assets, products and services. De-emphasizing the check and balance (governance) perspective of the industry is unwarranted as it will adversely affect the industry's sustainability in the long run. As the sacred industry develops, the increasing demand for competent shari'ah auditors is inevitable. The current shortages on qualified individuals in the labor market has effectively dampens the industry's vision to serve the ummah and becoming a viable alternative to conventional, shari'ah non-complaint finance.

This study finds that shari'ah audit has not been comprehensively introduced to the potential auditing labor market participants (i.e. the undergraduate students). This is despite the students are currently enrolled in Islamic finance, accounting, business and shari'ah courses. The students are however found to have at least some basic ideas of what shari'ah audit is all 
about, particularly on the roles and ethical characteristics of shari'ah auditor. Concentrated and coordinated efforts between the government, industry and academia are further required to ensure the continuous supply of knowledgeable and qualified shari'ah auditor are not disrupted, potentially giving disastrous impact to this shari'ah based industry.

\section{References}

AAOIFI (2010). Accounting, Auditing and Governance Standards for Islamic Financial Institutions. Manama, Bahrain: Accounting and Auditing Organization for Islamic Financial Institutions.

Besar, M.H.A., Abd-Sukor, M.E., Abdul-Muthalib, N., \& Gunawa, A.Y. (2009). The practice of Shari'ah review as undertaken by Islamic banking sector in Malaysia. International Review of Business Research Papers, 5(1), 294-306.

Courville, S. (2003). Social accountability audits: challenging or defending democratic governance?. Law \& Policy, 25(3), 269-297.

Dalci, I., Arasli, H., Tumer, M., \& Baradarani, S. (2013). Factors that influence Iranian students' decision to major in accounting. Journal of Accounting in Emerging Economies, 3(2), 145 - 163.

Garas, S.N., \& Pierce, C. (2010). Shari'a supervision of Islamic financial institutions. Journal of Financial Regulation and Compliance, 18(4), 386-407.

Ghauri, P., \& Gronhaug, K. (2010). Research methods in business studies. 4th edition, Pearson Education Limited, England.

Global Islamic Finance (2012). Shari’ah compliant assets expected to reach \$1.6Trn. Global Islamic Finance Magazines, 1-3.

Grais, W., \& Pellegrini, M. (2006). Corporate governance and shari'ah compliance in institutions offering Islamic financial services. World Bank Policy Research Working Paper No. 4054, The World Bank, New York, USA.

Grewal, B.K. (2012). Global Islamic Finance Statistics. Presentation at the Global Islamic Finance Forum 2012: Bridging Economies, Introductory Session \& GIFF Report, KFH Research Limited.

Gul, F. A., Andrew, B.H., Leong, S.C., \&Ismail, S. (1989). Factors influencing choice of discipline of study- accountancy, engineering, law and medicine. Accounting and Finance, 29(2), 93-100.

Haniffa, R., \& Hudaib, M. (2010). Islamic finance: from sacred intentions to secular goals?. Journal of Islamic Accounting and Business Research, 1(2), 85-91

International Monetary Fund. (2011). International Financial Statistics. http://www.imf.org/external/data.htm\#data 
Jackling, B., \& Calero, C. (2006). Influences on undergraduate students' intentions to become qualified accountants: Evidence from Australia. Accounting Education: An international Journal, 15(4), 419-438.

Karim, R.A.A. (1990). The independence of religious and external auditors: the case of Islamic banks. Accounting, Auditing and Accountability Journal, 3(3), 34 - 44.

Kasim, N., Mohamed-Ibrahim, S.H., \& Sulaiman, M. (2009). Shari'ah auditing in Islamic financial institutions: exploring the gap between the 'desired' and the 'actual'. Global Economy and Finance Journal, 2(2), 127-137.

Kasim, N. (2010). Auditing from the Islamic perspective. Accountants Today, Malaysian Institute of Accountants, 28 - 31.

Khan, M.A. (1985). Role of the auditor in an Islamic economy. Journal of Research in Islamic Economics, 3(1), 31- 42.

Mauldin, S., Crain, J.L., \& Mounce, P.H. (2000). The accounting principles instructors' influence on students' decision to major in accounting. Journal of Education for Business, 75(3), 142-148.

Mohamed-Ibrahim, S.H. (2008). The Case of Shari'ah Auditing. International Accountant (Feature section), 21-25, Available at www.kantakji.com/fiqh/Files/Accountancy/v181.pdf

Nahar, H.S., \& Yaacob, H. (2011). Accountability in the sacred context: The case of management, accounting and reporting of a Malaysian cash awqaf institution. Journal of Islamic Accounting and Business Research, 2(2), 87-113, http://dx.doi.org/10.1108/17590811111170520

Paolillo, J.G.P., \& Estes, R.W. (1982). An empirical analysis of career choice factors among accountants, attorneys, engineers, and physicians. The Accounting Review, 57(4), 785-793.

PwC (2011). Shari'ah Audit: Industry Insights. PriceWaterhouseCoopers Malaysia. Available at www.pwc.com/my

Rammal, H.G., \& Parker, L.D. (2010). Audit and governance in Islamic banks: Selection and training of shari'ah advisors. $6^{\text {th }}$ Asia Pacific Interdisciplinary Research in Accounting (APIRA) Conference Sydney, Australia. http://apira2010.econ.usyd.edu.au.

Shafii, Z., Salleh, S., \& Shahwan, S. (2010). Management of shari'ah non-compliance audit risk in the Islamic financial institutions via the development of shari'ah compliance audit framework and shari'ah audit programme. Kyoto Bulletin of Islamic Area Studies, 3(2), 3-16.

Sultan, S.A.M. (2007). A mini guide to shari'ah audit for Islamic financial institutions. CERT Publication, Kuala Lumpur.

United Nation. (2011). Human Development Reports. http://hdr.undp.org/en/statistics/

US Department of State. (2011). Background Note: Brunei. available online at http://www.state.gov/r/pa/ei/bgn/2700.htm. 


\section{Macrothink}

Asian Journal of Finance \& Accounting ISSN 1946-052X 2013, Vol. 5, No. 2

Yaacob, H. (2012). Issues and Challenges of Shari'ah Audit in Islamic Financial Institutions: A Contemporary View. in $3^{\text {rd }}$ Business and Economic Research International Conference (ICBER) 2012 proceedings of the international conference in Bandung, Indonesia, 2012.

Yaacob, H., \& Donglah, N.K. (2012). Shari'ah Audit in Islamic Financial Institutions: The Postgraduates' Perspective. International Journal of Economics and Finance, 4(12), 224 239.

Yavas, U., \& Arsan, N. (1996). Image of auditing as a field of study and a career among college students. Managerial Auditing Journal, 11(5), 41-44. 